\title{
Gambaran Kadar Bilirubin Total pada Penderita Tuberkulosis Paru dengan Terapi Obat Anti Tuberkulosis (Oat) di Puskesmas Poasia Kota Kendari
}

\author{
Firdayanti ${ }^{1}$, Angriani Fusvita ${ }^{2}$, Ani Umar ${ }^{3}$ \\ Prodi D-III Analis Kesehatan, Politeknik Bina Husada Kendari ${ }^{1,2,3}$ \\ firdayanti.damiru88@gmail.com ${ }^{1}$
}

Diajukan 25 Maret 2019 Diperbaiki 15 Mei 2019 Diterima 19 Agustus 2019

\section{ABSTRAK}

Latar Belakang: Pengobatan tuberkulosis dengan menggunakan Obat Anti Tuberkulosis (OAT) dapat diterima dalam terapi, akan tetapi mempunyai efektoksik yang potensial seperti efek samping reaksi hematologik yaitu anemia, agranulositosis, eosinofilia dan trombositopenia, serta terhadap fungsi hati. Hiperbilirubinemia adalah salah satu efek samping penggunaan OAT yang sering dikeluhkan oleh pasien. Penderita tuberkulosis di Puskesmas Poasia mengalami peningkatan tiap tahunnya, jika dibandingkan dengan Puskesmas lainnya di kota Kendari. Pada tahun 2017, pasien yang datang melakukan pemeriksaan sebanyak 431 orang, dengan hasil positif sebanyak 50 orang.

Tujuan: Mengetahui gambaran kadar bilirubin total pada penderita tuberkulosis dengan terapi OAT di Puskesmas Poasia Kota Kendari

Metode: Penelitian ini bersifat deskriptif dengan desain secara cross-sectional study pada pemeriksaan bilirubin menggunakan metode Jendrassik-Grof secara spektrofotometer. Populasi pasien positif TB sebanyak 50 orang. Pemeriksaan bilirubin total dilakukan pada 18 pasien tuberkulosis paru yang mendapatkan terapi OAT di Puskesmas Poasia Kota Kendari sebagai sampel yang diperoleh secara accidental sampling. Data yang diperoleh dianalisis secara deskriptif.

Hasil: Hasil penelitian menunjukkan bahwa dari 18 sampel yang dilakukan pemeriksaan, terdapat 10 sampel (56\%) dengan kadar bilirubin tinggi (hiperbilirubinemia) dan 8 sampel (44\%) memiliki kadar bilirubin normal.

Kesimpulan: Penderita tuberkulosis dengan penggunaan OAT memiliki resiko tinggi hiperbilirubinemia, dengan dijumpai $56 \%$ penderita TB dengan kadar bilirubin tinggi di Puskesmas Poasia Kota Kendari.

Kata Kunci: bilirubin; hiperbilirubinemia; OAT; terapi; tuberkulosis

\section{ABSTRACT}

Background: Treatment of tuberculosis using antituberculosis drugs (OAT) can be accepted in therapy, but has potential effectiveness such as the side effects of hematologic reactions, namely anemia, agranulocytosis, eosinophilia and thrombocytopenia, and liver function. Hyperbilirubinemia is one of the side effects of using OAT which is often complained by patients. Tuberculosis sufferers in Poasia Health Center have increased every year compared to other Puskesmas in Kendari city. In 2017 , there were 431 patients who came to examine, with 50 positive results.

Objective: To determine the description of total bilirubin levels in tuberculosis patients with OAT therapy at the Poasia Health Center in Kendari City

Method: This study was descriptive with a crosssectional study design on examination of bilirubin using a spectrophotometer Jendrassik-Grof method. The population of TB positive patients is 50 people. Total bilirubin examination was carried out on 18 pulmonary tuberculosis patients who received OAT therapy at Kendari City Poasia Health Center as a sample obtained by accidental sampling. The data obtained were analyzed descriptively.

Results: The results showed that from 18 samples examined, there were 10 samples (56\%) with high bilirubin levels (hyperbilirubinemia) and 8 samples (44\%) having normal bilirubin levels.

Conclusion: Patients with tuberculosis with the use of OAT have a high risk of hyperbilirubinemia, with $56 \%$ of TB patients with high bilirubin levels in the Poasia Health Center Kendari City.

Keywords: bilirubin; hyperbilirubinemia; OAT, therapy; tuberculosis 


\section{PENDAHULUAN}

Tuberkulosis merupakan salah satu penyakit menular langsung yang disebabkan oleh bakteri Mycobacterium tuberculosis. Sebagian besar bakteri Tuberkulosis menyerang paru, dan juga dapat menginfeksi organ tubuh lainnya. Bakteri ini memiliki ukuran 0,5-4 mikron x 0,3-0,6 mikron berbentuk batang tipis, lurus atau agak bengkok, berglanula atau tidak memiliki selubung, tetapi mempunyai lapisan luar tebal yang terdiri dari lipoid (Ilmiah et al., 2016). Penularan terjadi ketika pasien Tuberkulosis batuk atau bersin, kuman tersebar ke udara dalam bentuk percikan dahak (dropletnuclei). Infeksi terjadi apabila orang lain menghirup udara yang mengandung percikan dahak infeksius tersebut (Kementerian Kesehatan, 2015).

Laporan dari World Health Organization (WHO) menunjukan bahwa hampir 9 juta kasus baru terjadi pada tahun 2013 dan 1,5 juta kematian akibat Tuberkulosis. Indonesia merupakan bagian dari Asia Tenggara menempati urutan kedua Tuberkulosis tertinggi setelah India (Zumla et al., 2015). Penyakit ini juga menjadi penyebab kematian urutan ketiga setelah penyakit jantung dan penyakit saluran pernapasan. Menurut profil kesehatan Indonesia pada tahun 2015 terjadi peningkatan kasus TB paru dari tahun sebelumnya yaitu 324.539 kasus menjadi 330.910 kasus (Thuraidah, 2016).

Pengobatan Tuberkulosis dengan Obat Anti Tuberkulosis (OAT) utama meliputi isoniazid, rifampisin, etambutanol, streptomisin, dan pirazinamid memberikan efek samping yang berbeda-beda. Isoniazid dapat menyebabkan demam, reaksi hematologic seperti anemia, agranulositosis, eosinofilia dan trombositopenia. Rifampisin juga mempunyai efek samping terhadap reaksi hematologic seperti anemia dan trombositopenia. Walaupun sebagian besar Obat Anti Tuberkulosis (OAT) dapatditerima dalam terapi, akan tetapi dapat mempunyai efektoksik yang potensial diantaranya terhadap efek samping reaksi hematologic seperti anemia, agranulositosis, eosinofilia dan trombositopenia, dan terhadap fungsi (Thuraidah, 2016).

Gangguan fungsi hati adalah salah satu efek samping akibat penggunaan Obat Anti Tuberkulosis (OAT) yang sering dikeluhkan oleh penderita tuberkulosis. Kasus ini sering disebut Anti Tuberculosis drug induced hepatotoxicity. Ketiga OAT yaitu isoniazid, rifampicin, dan pirazinamid merupakan obat yang dapat menyebabkan hepatotoksitas, karena ketiganya dimetabolisme di hati. Pemeriksaan fungsi hati dapat dilakukan dengan beberapa pemeriksaan untuk mencegah efek samping dari OAT yaitu pemeriksaan SGOT, SGPT dan Bilirubin Total (Pontoh, Polii and Gosal, 2016).

Bilirubin merupakan pigmen kristal, bentuk akhir dari pemecahan hasil katabolisme melalui proses reaksi oksidasi-reduksi (Wong et al., 2007). Hiperbilirubinemia mempunyai makna terjadinya peningkatan kadar bilirubin dalam darah, ini bisa berupa peningkatan kadar bilirubin tidak terkonjugasi, maupun bilirubin yang terkonjugasi. Pada penelitian sebelumnya yang telah dilakukan oleh Pontoh et al. 2016 menunjukkan bahwa terdapat 15 pasien TB Paru yang mengalami peningkatan kadar bilirubin serum total yang sedang menjalani pengobatan OAT.

\section{METODE}

Jenis penelitian ini adalah deskriptif kuantitatif dengan desain secara cross-sectional study untuk mengetahui gambaran kadar bilirubin total pada penderita tuberkulosis yang mendapatkan terapi OAT di Puskesmas Poasia Kota Kendari. Populasi sampel sebanyak 50 penderita tuberkulosis di Puskesmas Poasia Kota Kendari. Pemeriksaan bilirubin total dilakukan pada 18 orang penderita tuberkulosis yang telah mendapatkan terapi OAT sebagai sampel yang diperoleh secara accidental sampling. Sampel yang digunakan adalah serum penderita tuberkulosis, yang selanjutnya ditambahkan reagen bilirubin total pada masing-masing 
sampel dan dilakukan pembacaan pada alat spektrofotometer. Pemeriksaan bilirubin total menggunakan metode pemeriksaan JendrassikGrof dan hasil dibaca secara spektrofotometer. Data hasil penelitian dianalisis secara deskriptif, disajikan dalam bentuk tabel.

\section{HASIL DAN PEMBAHASAN}

Berdasarkan hasil penelitian dari pemeriksaan bilirubin $\mathrm{t}$ otal pada 18 sampel serum penderita tuberkulosis yang telah mendapatkan terapi OAT diperoleh hasil bahwa lama pengobatan OAT cukup berpengaruh terhadap kadar bilirubin total penderita tuberkulosis. Distribusi data pasien berdasarkan Lama pengobatan OAT penderita tuberkulosis ditunjukkan pada tabel 1.

Tabel 1. Distribusi hasil berdasarkan lama pengobatan pasien yang mendapat perawatan paket Obat Anti Tuberkulosis (OAT) di Puskesmas Poasia Kota Kendari.

\begin{tabular}{ccc}
\hline $\begin{array}{c}\text { Lama } \\
\text { Pengobatan }\end{array}$ & $\begin{array}{c}\text { Frekuensi } \\
\text { (Pasien) }\end{array}$ & $\begin{array}{c}\text { Persentase } \\
\mathbf{( \% )}\end{array}$ \\
\hline 1-3 Bulan & 11 & 61 \\
4-6 Bulan & 7 & 39 \\
\hline Total & 18 & 100 \\
\hline
\end{tabular}

Tabel 1 menunjukkan data bahwa terdapat 11 pasien (61\%) telah mendapatkan terapi OAT selama 1-3 bulan, dan terdapat 7 pasien $(39 \%)$ telah mendapatkan terapi OAT selama 4-6 bulan. Lama pengobatan OAT pada penderita tuberkulosis menjadi salah satu faktor resiko adanya efek samping dari penggunaan OAT, seperti peningkatan kadar bilirubin. Isoniazid, rifampicin, dan pirazinamid merupakan obat yang dapat menyebabkan hepatotoksitas, karena ketiga obat tersebut dimetabolisme dalam organ hati. Hepatotoksitas dapat ditandai dengan peningkatan enzim hati dan kadar bilirubin. Peningkatan kadar bilirubin pada penderita tuberkulosis yang telah mendapatkan terapi OAT ditunjukkan pada tabel 2.
Tabel 2. Hasil pemeriksaan bilirubin total pada penderita TB paru mendapat perawatan paket Obat Anti Tuberkulosis (OAT) di Puskesmas

Poasia Kota Kendari.

\begin{tabular}{ccc}
\hline $\begin{array}{c}\text { Kadar } \\
\text { Bilirubin }\end{array}$ & $\begin{array}{c}\text { Jumlah } \\
\text { (Orang) }\end{array}$ & $\begin{array}{c}\text { Persentase } \\
\mathbf{( \% )}\end{array}$ \\
\hline $\begin{array}{c}\text { Normal } \\
(\leq 1 \mathrm{mg} / \mathrm{dL}) \\
\text { Tinggi } \\
(\geq 1 \mathrm{mg} / \mathrm{dL})\end{array}$ & 8 & 44 \\
\hline Total & 10 & 56 \\
\hline
\end{tabular}

Tabel 2 menunjukkan hasil pemeriksaan kadar bilirubin total penderita TB paru di Puskesmas Poasia Kendari. Data tersebut menunjukkan terdapat 10 (56\%) penderita TB paru yang memiliki kadar bilirubin tinggi (hiperbilirubinemia) dan 8 (44\%) penderita TB paru memiliki kadar bilirubin normal. Efek dari pemakaian OAT dapat menyebabkan ganguan fungsi hati, yang termasuk kedalam fungsi hati salah satunya adalah bilirubin. Obat Anti Tuberkulosis (OAT) yaitu isoniazid, rifampicin, dan pirazinamid merupakan tiga obat yang dapat menyebabkan hepatotoksitas, karena ketiganya dimetabolisme di hati, tetapi kedua Obat Anti Tuberkulosis (OAT) yaitu etambutol dan streptomisin tidak menyebabkan hepatotoksik. Pemberian empat regimen pengobatan sekaligus selama 2 bulan dapat terjadinya inhibisi pada sekresi sintesis empedu dan ekskresi dari asam empedu dan bilirubin dan kolesterol dalam empedu (Pontoh, Polii and Gosal, 2016).

Desrochers et al, 2011 melaporkan bahwa seorang anak perempuan yang mengalami gagal hati progresif karena profilaksis INH. Hal ini menyoroti potensi keparahan cedera hati terkait INH dan menggarisbawahi pentingnya pemantauan klinis yang waspada sepanjang durasi terapi OAT khususnya pada anak-anak (Desrochers et al., 2011). Pentingnya untuk memperhatikan kemungkinan terjadinya DILI (drug-induced liver injury) dengan tingkat bilirubin lebih dari 2,0 mg/dL ketika merawat pasien tuberculosis (Kato et al., 2013). Pada keadaan hepatotoksik terdapat kerusakan sel 
hati yang akan menyebabkan terjadinya mikroobstruksi di hepar (Makay, Rambert and Wowor, 2017). Bilirubin disaring dari darah oleh hati dan dikeluarkan pada cairan empedu. Sebagaimana hati menjadi semakin rusak, bilirubin total akan meningkat (Kosasih and Kosasih, 2008). Bilirubin merupakan hasil penguraian hemoglobin oleh sistem retikuloendotel dan dibawa ke dalam plasma menuju hati untuk melakukan proses konjugasi (langsung), bilirubin yang terkonjugasi (direk) dapat larut dalam air sedangkan bilirubin yang tidak terkonjugasi (indirek) tidak dapat larut dalam air. Nilai bilirubin total didapatkan dengan melepaskan ikatan albumin pada bilirubin indirek sehingga dapat larut dalam air dan dapat bereaksi (Kosasih and Kosasih, 2008).

\section{KESIMPULAN}

Berdasarkan hasil penelitian yang telah dilakukan Penderita tuberkulosis dengan penggunaan OAT memiliki resiko tinggi

hiperbilirubinemia, dengan dijumpai $56 \%$ penderita TB dengan kadar bilirubin tinggi di Puskesmas Poasia Kendari.

\section{DAFTAR PUSTAKA}

Desrochers, D. et al. (2011) 'Isoniazid-induced severe hepatotoxicity: an infrequent but preventable cause of liver failure in children treated for latent tuberculosis infection', Clinical Medicine Insights: Pediatrics. SAGE Publications Sage UK: London, England, 5, p. CMPed-S6406.

Ilmiah, K. T. et al. (2016) 'BULAN KE II DAN AKHIR BULAN KE VI DI RSUD CIAMIS TAHUN 2016 PROGRAM STUDI D3 ANALIS KESEHATAN SEKOLAH T INGG I I L MU KESEH A T A N MUHAMMADIYAH'.

Kato, H. et al. (2013) `Risk factors for liver injury with an elevated serum bilirubin concentration caused by antituberculous drugs', Internal medicine. The Japanese Society of Internal Medicine, 52(19), pp. 2209-2214.
Kementerian Kesehatan, R. I. (2015) 'Data dan Informasi Tahun 2014 (Profil Kesehatan Indonesia)', Jakarta: Kementerian Kesehatan Republik Indonesia.

Kosasih, E. N. and Kosasih, A. S. (2008) 'Tafsiran hasil pemeriksaan laboratorium klinik', Tangerang: Karisma Publishing Grup.

Makay, F., Rambert, G. I. and Wowor, M. F. (2017) 'Medical Laboratory Technology', 3(2), pp. 42-46.

Pontoh, L. G., Polii, E. B. I. and Gosal, F. (2016) 'Gambaran bilirubin dan urobilinogen urin pada pasien tuberkulosis paru', 4, pp. 0-5.

Thuraidah, 2017 (2016) 'Gambaran kadar bilirubin pasien tuberkulosis paru selama pengobatan di RSUP Prof . Dr . R . D . Kandou Manado', 4(April).

Wong, R. J. et al. (2007) 'Neonatal Jaundice : Bilirubin Physiology and Clinical Chemistry Neonatal Jaundice : Bilirubin Physiology and Clinical Chemistry The online version of this article, along with updated information and services, is located on the World Wide Web at ':, (October 2015). doi: 10.1542/neo.8-2-e58.

Zumla, A. et al. (2015) 'The WHO 2014 global tuberculosis report-further to go', The Lancet Global Health. Elsevier, 3(1), pp. e10-e12. 